\title{
Reduction of the East Asian winter monsoon interannual variability after the mid-1980s and possible cause
}

\author{
HE ShengPing ${ }^{1,2,3}$ \\ ${ }^{1}$ Nansen-Zhu International Research Center, Institute of Atmospheric Physics, Chinese Academy of Sciences, Beijing 100029, China; \\ ${ }^{2}$ Climate Change Research Center, Chinese Academy of Sciences, Beijing 100029, China; \\ ${ }^{3}$ Graduate University of Chinese Academy of Sciences, Beijing 100049, China
}

Received July 1, 2012; accepted August 7, 2012; published online October 12, 2012

\begin{abstract}
The East Asian winter monsoon (EAWM) consists of subsystems such as the Siberian high, Aleutian low, East Asian trough, low-level northerly wind and high-level East Asian jet stream. It is revealed that the interannual variation of the EAWM-related atmospheric circulation has exhibited an obvious weakening since the mid-1980s. During 1956-1980, significant negative correlations between the EAWM and sea surface temperature are observed in the oceans along the east coast of East Asia, accompanied by significant positive correlations in the western Warm Pool. However, the significant interannual relationship in the previous period is found to have been disrupted during 1986-2010. Further analysis reveals that the Arctic Oscillation after the mid-1980s tends to suppress the interannual variability of the EAWM. In addition, it was found that the large-scale warming after the mid-1980s is favorable to reduce the land-sea thermal contrast variability on both the interdecadal and interannual time scales.
\end{abstract}

East Asian winter monsoon, interannual variability, SST, global warming

Citation: He S P. Reduction of the East Asian winter monsoon interannual variability after the mid-1980s and possible cause. Chin Sci Bull, 2013, 58: 1331-1338, doi: $10.1007 / \mathrm{s} 11434-012-5468-5$

The East Asian winter monsoon (EAWM) is the dominant climate feature over East Asia during boreal winter. The variation of the EAWM has substantial impacts in many Asian countries. For instance, a strong EAWM is often accompanied by cold waves and snowstorms in Japan, Korea and northern China [1-3] and by persistent cooling of air temperatures in South China [4,5]. The severe freezing disaster that struck South China in January 2008 is attributed to the EAWM-related circulation anomalies induced by La Niña [6].

One of the most striking features of the EAWM is the cold Siberian high, which occupies almost the entire eastern Eurasian continent, with strong northwesterly wind along the high's east flank. A broad East Asian trough is centered along the longitudes of Japan at the middle troposphere. Additionally, the upper troposphere is characterized by the East Asian jet stream, with its maximum located in the

email: hshp@mail.iap.ac.cn south of Japan. Many previous studies have indicated that the variation of the above-mentioned subsystems of the EAWM can reflect the intensity of the EAWM. To our knowledge, at least 18 EAWM indices (Table 1) have been proposed based on these subsystems, such as pressure [7-13], low-level wind [14-17], East Asian jet stream [18,19], East Asian trough [20,21] and integrated indices [22-24]. However, no matter which definition is chosen for the EAWM, there is an obvious interdecadal weakening around the mid1980s [24]. Some studies have focused on this interdecadal variation of the EAWM since the mid-1980s [12,25]. The interdecadal weakening of the EAWM would lead to an increase in the winter surface air temperature and a decrease in the frequency of cold waves over East Asia [12,24,25]. The EAWM is also characterized by interannual variability. In recent years, the interannual variability of the EAWM and related driving factors (e.g. Arctic Oscillation (AO); El Niño-Southern Oscillation (ENSO); Hadley circulation; Antarctic Oscillation) has been extensively studied [26-29]. 
Table 1 Description of different definitions of the EAWM ${ }^{\text {a) }}$

\begin{tabular}{|c|c|c|}
\hline Index & Defining variable(s), level, and region & Reference \\
\hline$I_{\mathrm{XJ}}$ & $P_{\mathrm{s}}^{\text {norm }}\left(30^{\circ}-40^{\circ} \mathrm{N}, 100^{\circ}-120^{\circ} \mathrm{E}\right)-P_{\mathrm{s}}^{\text {norm }}\left(30^{\circ}-40^{\circ} \mathrm{N}, 130^{\circ}-140^{\circ} \mathrm{E}\right)$ & [7] \\
\hline$I_{\mathrm{GQY}}$ & $\left(P_{\mathrm{s} 110^{\circ} \mathrm{E}}-P_{\mathrm{S} 160^{\circ} \mathrm{E}}\right)_{\left(10^{\circ}-60^{\circ} \mathrm{N}\right)}$ & [8] \\
\hline$I_{\mathrm{SN}}$ & $\left(P_{\mathrm{s} 110^{\circ} \mathrm{E}}^{\text {norm }}-P_{\mathrm{s} 160^{\circ} \mathrm{E}}^{\text {norm }}\right)_{\left(20^{\circ}-50^{\circ} \mathrm{N}\right)}$ & [9] \\
\hline$I_{\mathrm{WW}}$ & $\left(P_{\mathrm{s} 110^{\circ} \mathrm{E}}^{\text {norm }}-P_{\mathrm{s} 160^{\circ} \mathrm{E}}^{\text {norm }}\right)_{\left(20^{\circ}-70^{\circ} \mathrm{N}\right)}$ & [10] \\
\hline$I_{\mathrm{CL}}$ & $P_{\mathrm{s}}^{\text {norm }}\left(30^{\circ}-55^{\circ} \mathrm{N}, 100^{\circ}-120^{\circ} \mathrm{E}\right)-P_{\mathrm{s}}^{\text {norm }}\left(30^{\circ}-55^{\circ} \mathrm{N}, 150^{\circ}-170^{\circ} \mathrm{E}\right)$ & [11] \\
\hline$I_{\mathrm{WHG}}$ & $\left(P_{\mathrm{s} 110^{\circ} \mathrm{E}}^{\text {norm }}-P_{\mathrm{s} 160^{\circ} \mathrm{E}}^{\text {norm }}\right)_{\left(40^{\circ}-70^{\circ} \mathrm{N}\right)}$ & [12] \\
\hline$I_{\mathrm{GWZ}}$ & $P_{\mathrm{s}},\left(40^{\circ}-60^{\circ} \mathrm{N}, 70^{\circ}-120^{\circ} \mathrm{E}\right)$ & [13] \\
\hline$I_{\mathrm{LC}}^{*}$ & $v, 1000 \mathrm{hPa},\left(7.5^{\circ}-20^{\circ} \mathrm{N}, 107.5^{\circ}-120^{\circ} \mathrm{E}\right)$ & [14] \\
\hline$I^{*} \mathrm{CS}$ & $v, 1000 \mathrm{hPa},\left(15^{\circ}-30^{\circ} \mathrm{N}, 115^{\circ}-130^{\circ} \mathrm{E}\right)$ & [15] \\
\hline$I^{*}{ }_{\mathrm{CHH}}$ & $v, 10 \mathrm{~m},\left(10^{\circ}-25^{\circ} \mathrm{N}, 110^{\circ}-130^{\circ} \mathrm{E}\right)+\left(25^{\circ}-40^{\circ} \mathrm{N}, 120^{\circ}-140^{\circ} \mathrm{E}\right)$ & [16] \\
\hline$I_{\mathrm{HLK}}$ & $-v, 10 \mathrm{~m},\left(15^{\circ}-40^{\circ} \mathrm{N}, 115^{\circ}-130^{\circ} \mathrm{E}\right)$ & [17] \\
\hline$I^{*}{ }_{\mathrm{YLK}}$ & $v, 850 \mathrm{hPa},\left(20^{\circ}-40^{\circ} \mathrm{N}, 100^{\circ}-140^{\circ} \mathrm{E}\right)$ & [18] \\
\hline$I_{\mathrm{JL}}$ & $u, 300 \mathrm{hPa},\left(27.5^{\circ}-37.5^{\circ} \mathrm{N}, 110^{\circ}-170^{\circ} \mathrm{E}\right)-\left(50^{\circ}-60^{\circ} \mathrm{N}, 80^{\circ}-140^{\circ} \mathrm{E}\right)$ & [19] \\
\hline$I^{*} \mathrm{SL}$ & $h, 500 \mathrm{hPa},\left(30^{\circ}-45^{\circ} \mathrm{N}, 125^{\circ}-145^{\circ} \mathrm{E}\right)$ & [20] \\
\hline$I^{*} \mathrm{CS}$ & $h^{\mathrm{Norm}}, 500 \mathrm{hPa},\left(35^{\circ}-40^{\circ} \mathrm{N}, 110^{\circ}-130^{\circ} \mathrm{E}\right)$ & [21] \\
\hline$I^{*} \mathrm{zLK}$ & 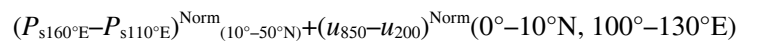 & [22] \\
\hline$I_{\mathrm{YZY}}$ & $\begin{array}{l}T_{\mathrm{s}}, 2 \mathrm{~m},\left(20^{\circ}-40^{\circ} \mathrm{N}, 110^{\circ}-135^{\circ} \mathrm{E}\right) \\
h, 500 \mathrm{hPa},\left(25^{\circ}-40^{\circ} \mathrm{N}, 115^{\circ}-140^{\circ} \mathrm{E}\right) \\
P_{s 160^{\circ}}-P_{s 110^{\circ}},\left(20^{\circ}-50^{\circ} \mathrm{N}\right) \\
P_{\mathrm{s}},\left(40^{\circ}-60^{\circ} \mathrm{N}, 80^{\circ}-125^{\circ} \mathrm{E}\right) \\
h, 500 \mathrm{hPa},\left(25^{\circ}-45^{\circ} \mathrm{N}, 110^{\circ} \mathrm{E}-145^{\circ} \mathrm{E}\right) \\
u, 300 \mathrm{hPa},\left(25^{\circ}-40^{\circ} \mathrm{N}, 80^{\circ}-180^{\circ} \mathrm{E}\right)-\left(45^{\circ}-60^{\circ} \mathrm{N}, 60^{\circ}-160^{\circ} \mathrm{E}\right)\end{array}$ & [23] \\
\hline
\end{tabular}

a) * Multiplied by -1 with respect to the original definition so that a high index corresponds to a strong EAWMI; norm denotes the normalization; $P_{\mathrm{s}}$, sea level pressure; $u$, zonal wind; $v$, meridional wind; $h$, geopotential height; $T_{\mathrm{s}}$, surface air temperature.

Wang and He [30] indicated that the ENSO-EAWM relationship has weakened after the mid-1970s due to the reduced EAWM interannual variability and changes of the Indo-Pacific SST interannual variability after the mid1970s.

Based on these previous studies, we reveal the weakening of the EAWM interannual variability after the mid1980 s in this research. We also try to understand the possible mechanisms for the reduced EAWM interannual variability after the mid-1980s compared with the pre-mid-1980s.

\section{Data}

The datasets used in this study include: (1) monthly-mean reanalysis data from the National Centers for Environmental Prediction/National Center for Atmospheric Research (NCEP/ NCAR) [31]; (2) monthly-mean sea surface temperature (SST) obtained from the National Oceanic and Atmospheric Administration (NOAA) Extend Reconstructed version 3 analysis data [32]; (3) the North Pacific Oscillation (NPO) index [33], which is defined as the principal component of the leading mode of the empirical orthogonal function analysis for the winter SLP over the North Pacific $\left(20^{\circ}-80^{\circ} \mathrm{N}\right.$, $120^{\circ}-120^{\circ} \mathrm{W}$ ); and (4) the AO index obtained from the National Weather Service Climate Prediction Center (http://
www.cpc.ncep.noaa.gov/products/precip/CWlink/daily_ao_ index/ao.shtml). To emphasize the interannual variability, the aforementioned variables were detrended. Seasonal mean are constructed from monthly mean by averaged the data of December, January, and February of 1956-2010.

\section{Weakening of the EAWM interannual variability}

Figure 1 shows the 23-year sliding standard deviation of the 18 existing EAWM indices. It is indicated that no matter which system the EAWM index (EAWMI) is defined as, its interannual variation always shows an obvious decline in recent decades, especially since the mid-1980s. This pattern means that, accompanied by the interdecadal weakening of the EAWM since the mid-1980s, the interannual variation of the EAWM-related circulation also becomes weaker. To document the interdecadal change in the interannual variation of the EAWM, we take two periods based on Figure 1: 1956-1980 (P1) and 1986-2010 (P2), each period consisting of 25 years.

Figure 2 presents the differences ( $\mathrm{P} 2$ minus $\mathrm{P} 1)$ of interannual variation, which is defined as the standard deviation of the EAWM-related circulation between 1956-1980 and 1986-2010. The figure shows that during the latter period, 

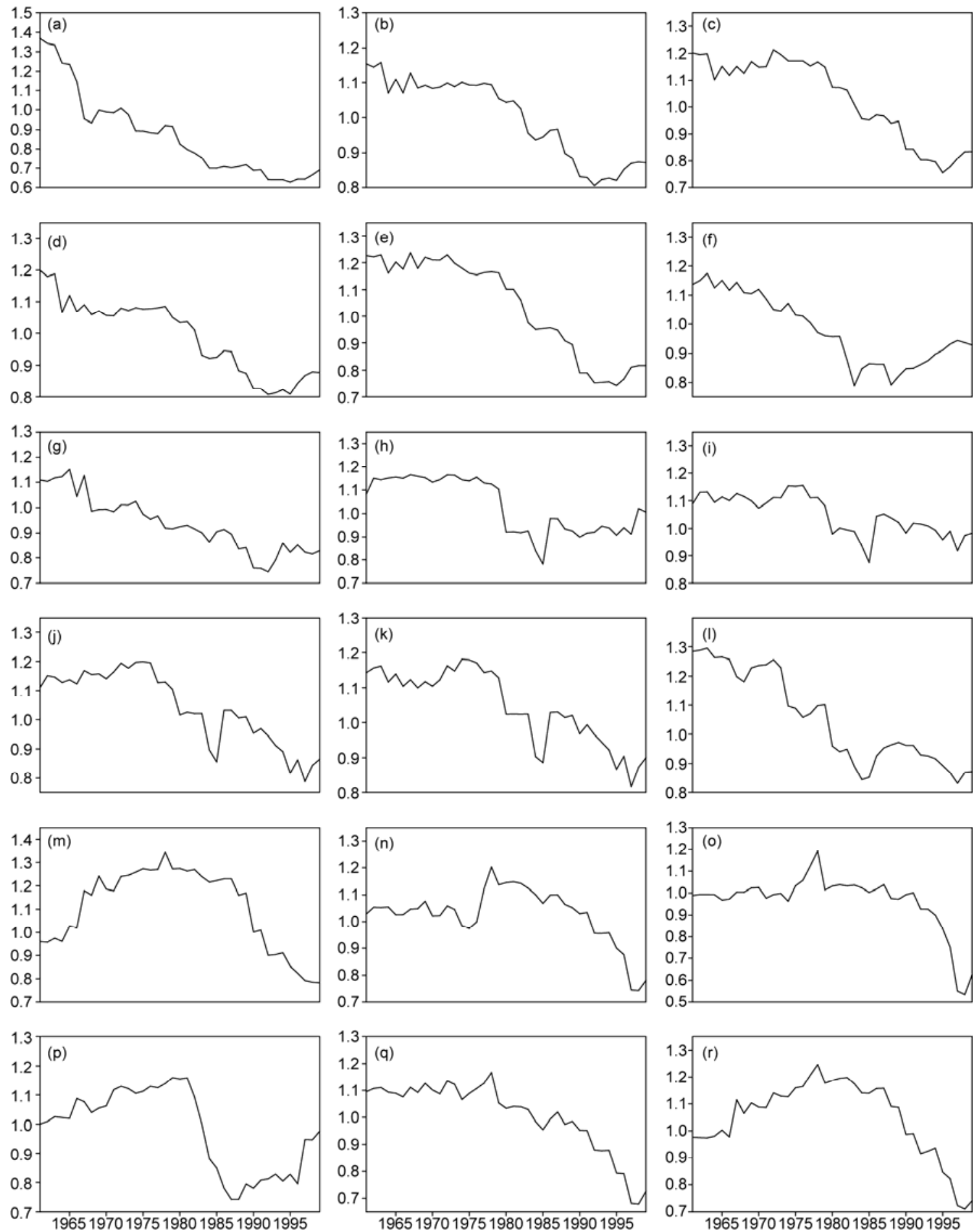

Figure 1 The 23-year sliding standard deviation of the 18 existing EAWM indices for 1950-2010 winters.

the interannual variation of the Siberian high is weakened, so is the Aleutian low (Figure 2(a)). In the $500 \mathrm{hPa}$ geopotential height field, negative differences larger than 3 are located in Siberia, Japan and the northern North Pacific (Figure 2(b)). The implication is that the magnitude of the interannual variation of the East Asian trough during 19862010 is less than that in the former period. In the $300 \mathrm{hPa}$ zonal wind field over East Asia, the negative values nearly cover the entire East Asian jet stream region (Figure 2(c)). Additionally, the interannual variation of the $850 \mathrm{hPa}$ meridional wind over East Asia in the latter period is also smaller than that during 1956-1980 (Figure 2(d)). The above analysis confirms that the interannual variation of the EAWM has weakened since the mid-1980s. 

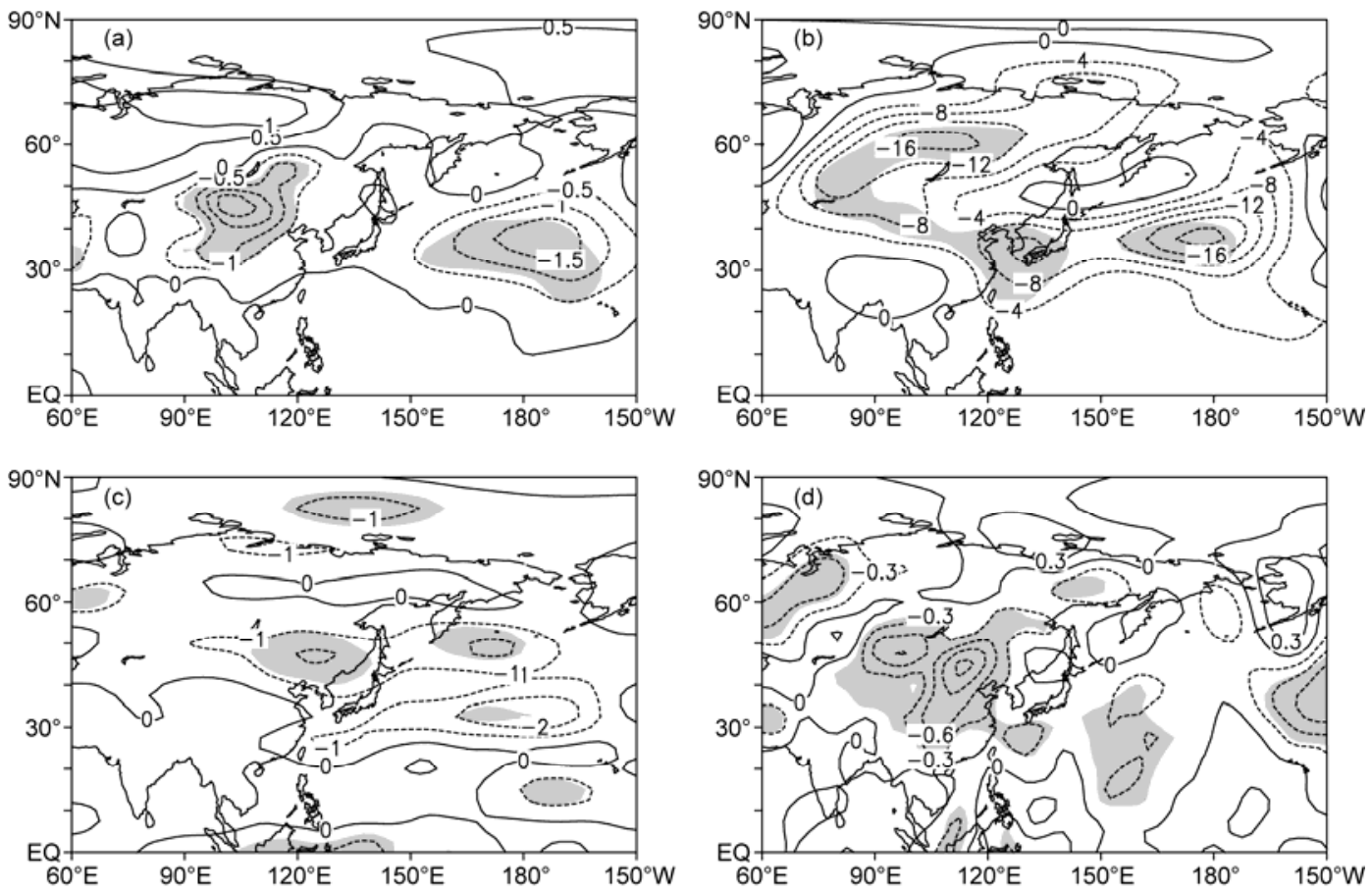

Figure 2 Differences (P2 minus P1) of standard deviation for the EAWM-related circulation between 1986-2010 (P2) and 1956-1980 (P1). (a) Sea level pressure; (b) $500 \mathrm{hPa}$ geopotential height; (c) $300 \mathrm{hPa}$ zonal wind; (d) $850 \mathrm{hPa}$ meridional wind. The regions shaded denote the values exceeding $95 \%$ confidence level.

To uncover whether the interannual relationship experiences noticeable change in the mid-1980s, we examine the correlation between the EAWMI [24] (defined as the mean geopotential height at $500 \mathrm{hPa}$ in the domain of $\left(25^{\circ}-45^{\circ} \mathrm{N}\right.$, $\left.110^{\circ}-145^{\circ} \mathrm{E}\right)$ ) and SST anomalies (SSTA) in the western North Pacific for 1956-1980 and 1986-2010, respectively (Figure 3). It is found that as the interannual variation of the EAWM becomes weak, the correlation pattern shows remarkable differences between the two periods. In 19561980, significant negative correlations were located in the oceans adjacent to East Asia, while positive correlations occurred in the Warm Pool (Figure 3(a)). These relationships between the EAWM and the western North Pacific SSTA have been revealed by many previous studies [34,35]. However, in 1986-2010, the negative correlations become insignificant and the range of significant positive correlations in the Warm Pool is considerably smaller. Apparently, the interannual relationship between the EAWM and SSTA in the western North Pacific has weakened since the mid1980s.

To validate the evolution of the interannual relationship between the EAWM and the western North Pacific SSTA, we introduce three SSTA indices, which are defined as area-averaged SSTA in the South China Sea $\left(5^{\circ}-25^{\circ} \mathrm{N}\right.$, $\left.105^{\circ}-120^{\circ} \mathrm{E}, \mathrm{SCI}\right)$, the Kuroshio Current region $\left(10^{\circ}-30^{\circ} \mathrm{N}\right.$, $\left.120^{\circ}-130^{\circ} \mathrm{E}, \mathrm{KCI}\right)$ and the Warm Pool $\left(0^{\circ}-16^{\circ} \mathrm{N}, 140^{\circ}-\right.$ $\left.160^{\circ} \mathrm{E}, \mathrm{WPI}\right)$. Figure 4 displays the 23 -year sliding correlation between the EAWMI and the three SSTA indices. Consistent with Figure 3, the EAWMI and the three indices show significant negative or positive correlations before the
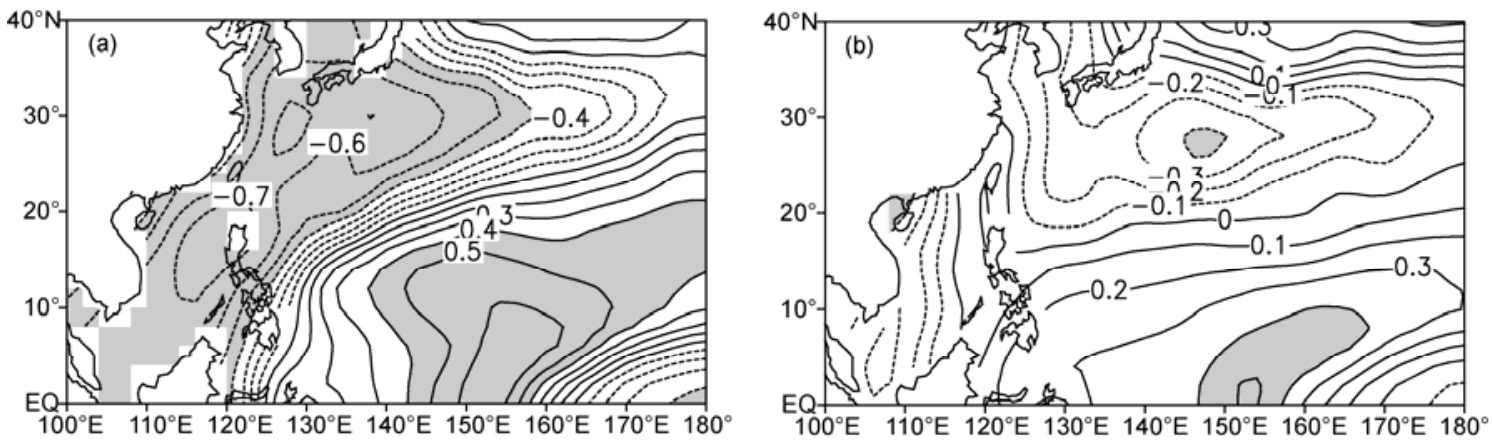

Figure 3 Correlation coefficients between EAWMI and winter SSTA in the western North Pacific during (a) 1956-1980 and (b) 1986-2010, respectively. The regions shaded denote the values exceeding $95 \%$ confidence level. 

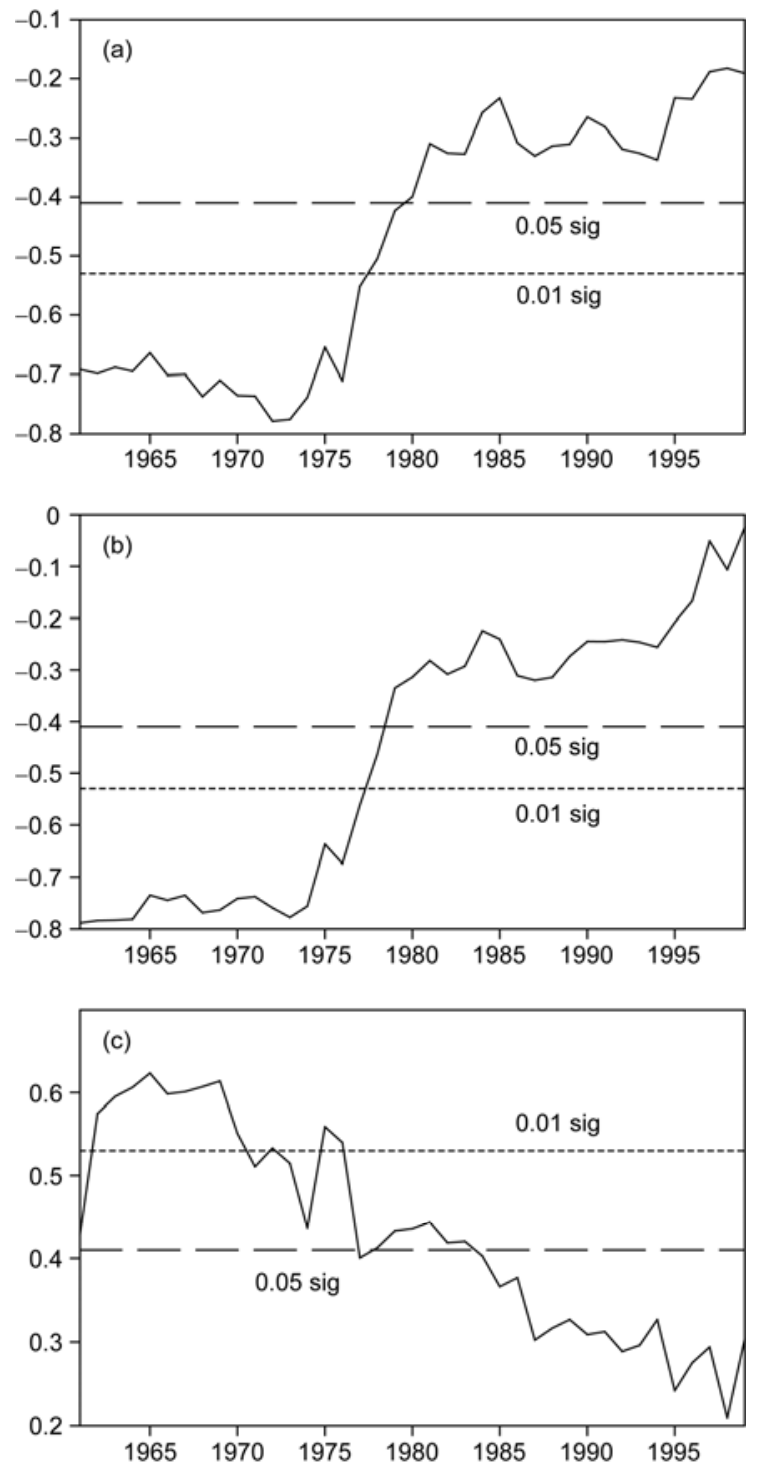

Figure 4 The 23-year sliding correlation of EAWMI with area-averaged SSTA over (a) South China Sea $\left(5^{\circ}-25^{\circ} \mathrm{N}, 105^{\circ}-120^{\circ} \mathrm{E}\right)$, (b) Kuroshio Current $\left(10^{\circ}-30^{\circ} \mathrm{N}, 120^{\circ}-130^{\circ} \mathrm{E}\right)$, and (c) Warm Pool $\left(0^{\circ}-16^{\circ} \mathrm{N}, 140^{\circ}-160^{\circ} \mathrm{E}\right)$. The dashed horizontal lines denote the $95 \%$ and $99 \%$ confidence levels.

1980s, followed by an obvious weakening of correlations around the mid-1980s. Further evidence comes from the specific correlation coefficient (CC) between the EAWMI and the three indices in the different periods. During 19562010, the correlation coefficients (CCs) of the EAWMI with SCI, KCI and WPI are $-0.45,-0.46$ and 0.34 , respectively. All the CCs can exceed the $99 \%$ confidence level. Therefore, it appears that the correlations between the EAWM and the western North Pacific SSTA are very close and stable. However, if we investigate the correlations in different periods, the situation is much different. In 1956-1980, for example, the EAWM is well concurrent with the western North Pacific SSTA and the CCs of EAWMI with SCI, KCI and WPI are $-0.69,-0.75$ and 0.63 , respectively. However, the CCs decline substantially to $-0.16,0.01$ and 0.29 , respectively, in 1986-2010.

\section{Discussion}

The identified changes in the interannual variability of the EAWM raise two questions: (1) What caused the weakening of the EAWM interannual variation? (2) Why is the interannual relationship between the EAWM and the western North Pacific SSTA significant in 1956-1980 but insignificant in 1986-2010?

The answer to the first question may be related to AO. As revealed by many previous studies, there is a significant out-of-phase relationship between the EAWM and the AO [36-38]. The AO maintains a mainly positive status since the late 1980s [39], which is conducive to a weak EAWM. Furthermore, the correlations between AO index and EAWMI and the NPO index become more significant in the recent three decades (Figure 5). These observations indicate that the winter AO events in 1986-2010 possibly exert an inhibiting effect on the development of the EAWM. However, because the interannual variation of the Siberian high, which plays an important role in connecting the AO and the EAWM [26], has weakened in recent decades (Figure 1(g)), the interannual variation of the EAWM is therefore suppressed.

Another possible answer to the first question may be the
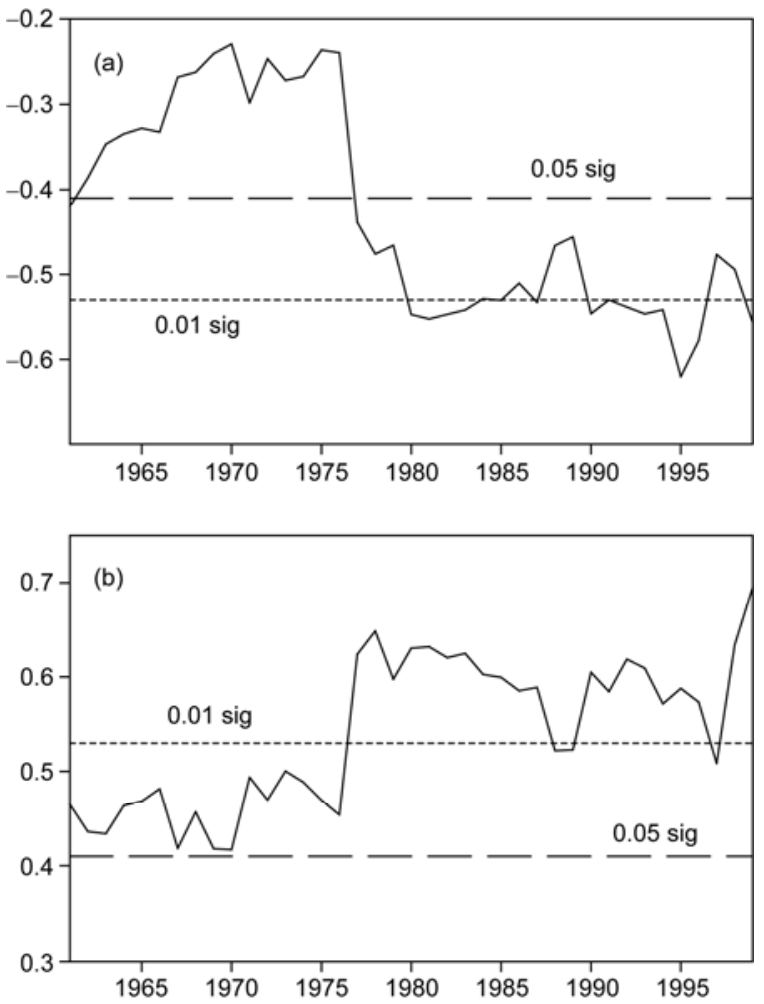

Figure 5 The 23-year sliding correlation between the AO index and EAWMI (a), NPO (b) indexes. The dashed horizontal lines denote the $95 \%$ and $99 \%$ confidence levels. 
global warming in recent decades. Within the context of global warming, both the continents and oceans have a warmer trend (not shown). Due to the enormous heat content of the oceans, the magnitude of the interannual increase of winter surface temperature over the western North Pacific is less than that over the East Asian continent. Consequently, the land-sea thermal gradient is weakened, leading to the weakened EAWM interannual variability. To identify the weakened land-sea thermal gradient, we introduce a thermal contrast index (THCI), which is defined as the difference between the area-averaged skin temperature over the East Asian continent $\left(20^{\circ}-40^{\circ} \mathrm{N}, 105^{\circ}-130^{\circ} \mathrm{E}\right)$ and the area-averaged SSTA over the western North Pacific $\left(10^{\circ}-20^{\circ} \mathrm{N}, 105^{\circ}-120^{\circ} \mathrm{E}\right.$ and $\left.20^{\circ}-36^{\circ} \mathrm{N}, 120^{\circ}-150^{\circ} \mathrm{E}\right)$. As shown in Figure 6 (thick line), both the interannual variation (thick line) and the 23-year sliding standard deviation of the THCI (solid cycle) show obvious weakening since the mid-1980s. It is indicated that the interannual variability of the land-sea thermal gradient between the East Asian continent and the western North Pacific does become smaller in recent decades, which likely contributes to the weakening of the interannual variation of the EAWM.

Figure 7 shows the correlations between the EAWMI and vorticity at $10 \mathrm{~m}$. During 1956-1980, significant negative correlations are located over East China and its eastern neighboring oceans and over the western Warm Pool, accompanied by significant positive correlations in east of Philippines (Figure 7(a)). This result suggests that northeasterly and southwesterly winds prevail along the east coast of East China and the western Warm Pool when the EAWM is stronger than normal. During 1986-2010, however, the connection between the EAWM and the vorticity over East China and east of Philippines is disrupted (Figure 7(b)), which is likely responsible for the weakened interannual relationship between the EAWM and SSTA in the western North Pacific.

\section{Conclusion}

This study indicates that most of the existing EAWM indices

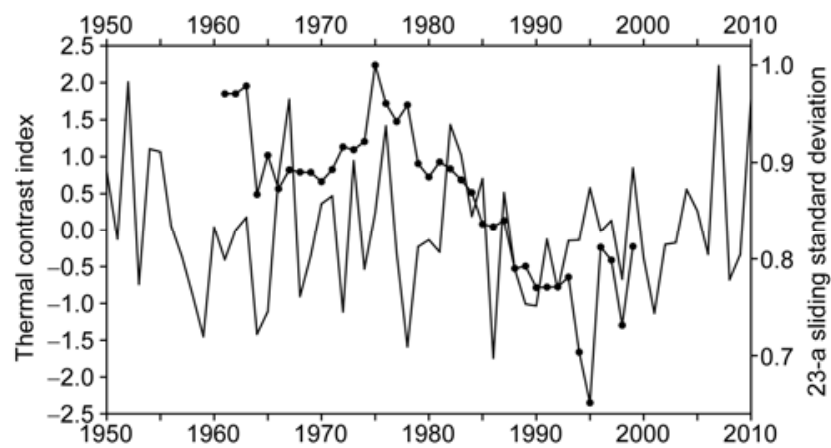

Figure 6 The interannual variation of THCI (thick solid line) during 1950-2010; and the standard deviation of THCI (solid cycle) calculated within a 23-year window that moves year by year from 1950-2010.
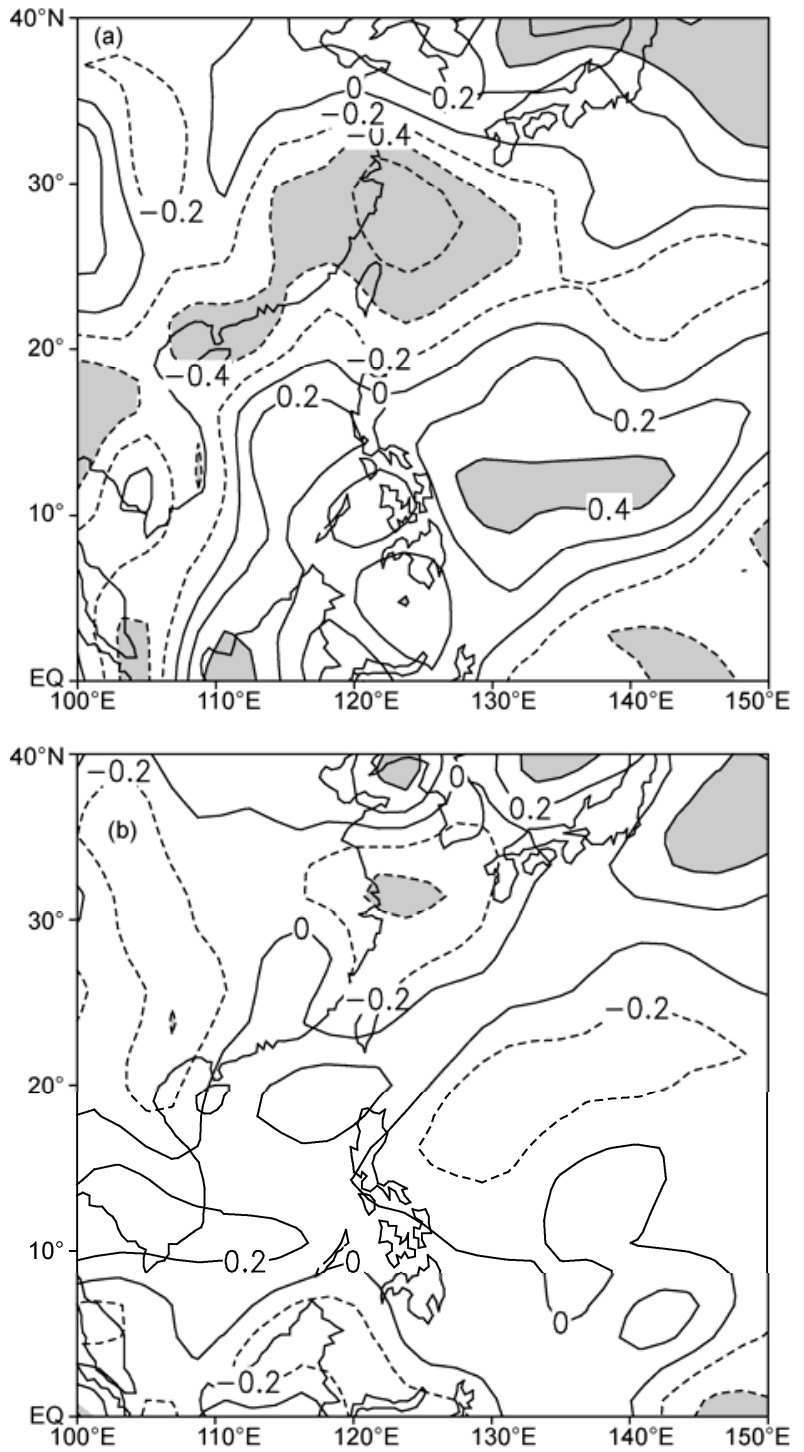

Figure 7 Correlation coefficients between EAWMI and vorticity at $10 \mathrm{~m}$ during (a) 1956-1980 and (b) 1986-2010 winters, respectively. The regions shaded denote the values exceeding $95 \%$ confidence level.

show an obvious weakening of interannual variability around the mid-1980s, concurrent with the interdecadal change of the EAWM. There are also evident changes in the EAWM-related atmospheric circulation. Compared with the situation during 1956-1980, the interannual variability of the Siberian high and the Aleutian low during 1986-2010 is much weaker. Additionally, the fluctuations of the East Asian trough, East Asian jet stream and meridional wind at 850-hPa during 1986-2010 are smaller on the interannual time scale than those in the former period. The above observational facts suggest that the interannual variability of the EAWM has weakened in the recent twenty more decades. It is also revealed that the interannual relationship between the EAWM and western North Pacific SSTA has weakened since the 1980s. During 1956-1980, significant negative correlations are found in regions stretching from 
the Japan Sea to the South China Sea and adjacent oceans, accompanied by significant positive correlations in the western Warm Pool. However, the magnitude of the correlations in these regions decreased substantially during 19862010.

Further analysis indicates that the interannual relationship between the AO and the EAWM has strengthened in recent three decades. Given that the AO mainly maintains a positive status in winter since the mid-1980s, the development of the EAWM may be significantly suppressed. Because the interannual variability of the Siberian high, which plays an important role in connecting the $\mathrm{AO}$ and the EAWM [26], has weakened since the mid-1980s, the AO is likely to be responsible for the weakening of the EAWM interannual variability. Global warming may be another possible factor responsible for the identified changes. Within the context of global warming, the magnitude of the warming trend over the East Asian continent is greater than that over the western North Pacific, leading to the weakening of the land-sea thermal contrast variability both on the interdecadal and interannual time scales. It should be pointed out that similar results would be obtained if we use the integrated EAWM index defined by He and Wang [24]. Future studies could focus on the long-term variability of the EAWM-associated extreme winter climate [40] and its connection with the Arctic climate change.

Thanks Prof. Wang Huijun for helpful discussions. Comments and helpful suggestions from the editor and two anonymous reviewers helped us to improve the presentation of our results. This work was supported by the National Natural Science Foundation of China (41130103) and the National Basic Research Program of China (2009CB421406).

1 Huang R H, Chen J L, Huang G. Characteristics and variations of the East Asian monsoon system and its impacts on climate disasters in China. Adv Atmos Sci, 2007, 24: 993-1023

2 Wang H J, Yu E T, Yang S. An exceptionally heavy snowfall in Northeast China: Large-scale circulation anomalies and hindcast of the NCAR WRF model. Meteor Atmos Phys, 2011, 113: 11-25

3 Wang H J, Sun J Q. Variability of northeast China river break-up date. Adv Atmos Sci, 2009, 26: 701-706

4 Sun J Q, Wang H J, Yuan W, et al. Spatial-temporal features of intense snowfall events in China and their possible change. J Geophys Res, 2010, 115: D16110

5 Li F, Wang H J. Predictability of the East Asian winter monsoon interannual variability as indicated by the DEMETER CGCMS. Adv Atmos Sci, 2012, 29: 441-454

6 Fu J J, Li S L, Wang Y M. Influence of prior thermal state of global oceans on the formation of the disastrous snow storm in January 2008 (in Chinese). Clim Environ Res, 2008, 13: 478-490

$7 \mathrm{Xu} \mathrm{S} \mathrm{Y,} \mathrm{Ji} \mathrm{J} \mathrm{J.} \mathrm{The} \mathrm{climate} \mathrm{and} \mathrm{weather} \mathrm{features} \mathrm{during} \mathrm{the} \mathrm{outbreak}$ period of China's winter monsoon (in Chinese). Geogr Sym, 1965, 9: 85-101

8 Guo Q Y. Relationship between the variations of East Asian winter monsoon and temperature anomalies in China (in Chinese). J Appl Meteor Sci, 1994, 5: 218-225

9 Shi N, Lu J J, Zhu Q G. East Asian winter/summer monsoon intensity indices with their climatic change in 1873-1989 (in Chinese). J Nanjing Inst Meteor, 1996, 19: 168-177

10 Wu B Y, Wang J. Winter Arctic Oscillation, Siberian high and East
Asian winter monsoon. Geophys Res Lett, 2002, 29, doi: 10.1029/ 2002GL015373

11 Chan J C L, Li C Y. The East Asian monsoon. In: Chang C P, ed. East Agian Monsoon. Singapore: World Scientific Publishing Co. Pet. Ltd, 2004. 54-106

12 Wang L, Huang R H, Gu L, et al. Interdecadal variations of the East Asian winter monsoon and their association with quasi-stationary planetary wave activity. J Clim, 2009, 22: 4860-4872

13 Gong D Y, Wang S W, Zhu J H. East Asian winter monsoon and Arctic Oscillation. Geophys Res Lett, 2001, 28: 2073-2076

14 Er Lu, Chan J C L. A unified monsoon index for South China. J Clim, 1999, 12: 2375-2385

15 Chen J, Sun S Q. East Asian winter wonsoon anomaly and variation of global circulation, Part I: A comparison study on strong and weak winter monsoon (in Chinese). Chin J Atmos Sci, 1999, 23: 101-111

16 Chen W, Graf H F, Huang R H. The interannual variability of East Asian winter monsoon and its relation to the summer monsoon. Adv Atmos Sci, 2000, 17: 48-60

17 Hu Z Z, Lennart B, Arpe K. Impact of global warming on the Asian winter monsoon in a coupled GCM. J Geophys Res, 2000, 105: 4607-4624

18 Yang S, Lau K M, Kim K M. Variations of the East Asian jet stream and Asian-Pacific-American winter climate anomalies. J Clim, 2002, 15: 306-325

19 Jhun J G, Lee E J. A new East Asian winter monsoon index and associated characteristics of the winter monsoon. J Clim, 2004, 11: 711-726

20 Sun B M, Li C Y. Relationship between disturbance of East Asian trough and tropical convection activities (in Chinese). Chin Sci Bull (Chin Ver), 1997, 42: 500-503

21 Cui X P, Sun Z B. East Asian winter monsoon index and its variation analysis (in Chinese). J Nanjing Inst Meteorol, 1999, 22: 321-325

22 Zhu C W, Lee Woo-Sung, Kang H W, et al. A proper monsoon index for seasonal and interannual variations of the East Asian monsoon. Geophys Res Lett, 2005, 32, doi: 10.102912004GL021295

23 Yan H M, Zhou W, Yang H, et al. Definition of a East Asian winter monsoon index and its variation characteristics (in Chinese). Trans Atmos Sci, 2009, 32: 367-376

24 He S P, Wang H J. An integrated East Asian winter monsoon index and its interannual variability (in Chinese). Chin J Atmos Sci, 2012, 36: $523-538$

25 Chang $\mathrm{C}$, Wang Z, Hendon $\mathrm{H}$. The Asian winter monsoon. In: Wang B, ed. The Asian Monsoon. Berlin: Springer Praxis Book, 2006. 89127

26 Gong D Y, Wang S W, Zhu J H. East Asian winter monsoon and Arctic Oscillation. Geophys Res Lett, 2001, 28: 2073-2076

27 Wang B, Wu R, Fu X. Pacific-east Asian teleconnection: How does ENSO affect East Asian climate? J Clim, 2000, 13: 1517-1536

28 Zhou B T, Wang H J. Interdecadal change in the connection between Hadley circulation and winter temperature in East Asia. Adv Atmos Sci, 2008, 25: 24-30

29 Fan K, Wang H J. Interannual variability of Antarctic Oscillation and its influence on East Asian climate during boreal winter and spring. Sci China Ser D-Earth Sci, 2006, 49: 554-560

30 Wang $\mathrm{H} \mathrm{J}$, He S P. Weakening relationship between East Asian winter monsoon and ENSO after mid-1970s. Chin Sci Bull, 2012, 57: 3535-3540

31 Kalnay E, Kanamitsu M, Kistler R, et al. The NCEP/NCAR 40-year reanalysis project. Bull Amer Meteorol Soc, 1996, 77: 437-471

32 Smith T M, Reynolds R W, Peterson T C, et al. Improvements to NOAA's historical merged land-ocean surface temperature analysis (1880-2006). J Clim, 2008, 21: 2283-2296

33 Linkin M E, Nigam S. The North Pacific Oscillation-west Pacific teleconnection pattern: Mature-phase structure and winter impacts. J Clim, 2008, 21: 1979-1997

34 Qin Z, Sun Z. Influence of abnormal East Asian winter monsoon on the northwestern Pacific sea temperature (in Chinese). Chin J Atmos Sci, 2006, 30: 257-267

35 Li C Y, Mu M Q. Relationship between East Asian winter monsoon, 
warm pool situation and ENSO cycle. Chin Sci Bull, 2000, 45: $1448-1455$

36 Wu B Y, Huang R H. Effects of the extremes in the North Atlantic Oscillation on East Asia winter monsoon (in Chinese). Chin J Atmos Sci, 1999, 23: 641-651

37 Liu J P, Curry J A, Wang H J, et al. Impact of declining Arctic sea ice on winter snowfall. Proc Natl Acad Sci USA, 2012, 109: 6781-6783

38 Sun J Q, Wang H J. Relationship between Arctic Oscillation and
Pacific Decadal Oscillation on decadal timescale. Chin Sci Bull, 2006, 51: 75-79

39 Wu B Y, Bian L G, Zhang R H. Effects of the winter AO and the Arctic sea ice variations on climate variation over East Asia (in Chinese). Chin J Polar Res, 2004, 16: 211-220

40 Wang H J, Sun J Q, Chen H P, et al. Extreme climate in China: Facts, simulation and projection. Meteorol Z, 2012, doi: 10.1127/09412948/2012/0330

Open Access This article is distributed under the terms of the Creative Commons Attribution License which permits any use, distribution, and reproduction in any medium, provided the original author(s) and source are credited. 